\title{
Response of natural forest regeneration to human disturbance in Banke National Park
}

\begin{abstract}
R. Napit ${ }^{1}$ and P. K. Paudel ${ }^{2}$
Tropical forest continues to decline in Nepal's lowlands, with a serious negative consequence for biodiversity conservation. Even a strict natural reserve is subjected to have some degree of human disturbances. The newly established Banke National Park of Nepal provides an excellent context to evaluate effects of human disturbances on the forest regeneration status. This article assesses the regeneration status of the park. A total of 1,067 plots were laid out within the park area. In each plot, three concentric rings of radii of $10 \mathrm{~m}, 5 \mathrm{~m}$, and $1 \mathrm{~m}$ were established. Data of seedling/ sapling and human disturbance variables were collected from each of the concentric plots. Principal component analysis (PCA) of all disturbance variables was carried out to generate a disturbance index. The findings of this study alienates with intermediate disturbance hypothesis. Cut wood, lopped tree, human/livestock trails, people number - are the significant variables for the impact of sapling and seedling density in the park. The induced human disturbances up to the limit avails the highest regeneration status in the park. These human disturbances might have induced the spatial heterogeneity and internal dynamics which help in the regeneration. The main challenge for the forest managers and scientists is to identify the indicators of environmental damage of forest and their threshold levels at which human disturbances will result in an irreversible decline of the vegetation and its regeneration.
\end{abstract}

Key words: Regeneration, human disturbances, impacts, Banke National Park

$\mathrm{D}$ eforestation and forest degradation are the human impediments to the forest's biological ability to reproduce itself. Forest resources are altered either by natural or by human induced factors. However, human induced activities are more aggressive and have influenced forest depletion in variety of ways. Disturbance also influences processes that can either augment or erode the ecological functions of a forest community (Sagar and Singh, 2005). Both natural and human disturbances influence forest dynamics and tree diversity at local and regional scales. Frequently, human individual disturbance factors e.g., selective logging have been highlighted in attempts to explain the structural attributes of forests (Vetaas, 2000; Sapkota et al., 2009). Despite multiple factors simultaneously altering ecosystem functioning, frequent and fluctuating disturbance factors e.g., grazing, browsing, firing, fuel wood and fodder collection have often been overlooked in explanations of post disturbance changes in forest ecosystems.

In Nepal, deforestation is a critical problem that cannot be solved so easily without appropriate policy and enforcement of strict rules. In the Terai and Siwalik regions, deforestation is quite common due to government resettlement programs and illicit clearing of forest for agriculture. In general, the main causes of deforestation in Nepal are conversion of forest areas for resettlements and cultivation, need for timber and fuel wood, forage for livestock as well as local unemployment and lack of management from the government. Besides, forest fire, shifting cultivation, natural process, forest rewards, attitude of individuals, donors role and government policy are other reasons for deforestation in the nation (Joshi et al., 2000). Share of forest land in the Terai was decreased by about $12 \%$ from 1986 to 2000 (from 0.2 ha in 1986 to 0.12 ha in 2000), (Panta, 2009). Despite

${ }^{1}$ Department of Environmental Science, Khwopa College, TU, Bhaktapur, Nepal, E-mail: renu.napit1@gmail.com

${ }^{2}$ Reseach Scientist, Conservation Nepal 
the initiation of community forest management system, human disturbance continues in various forms including setting fire (Kuwar et al., 2004). About $90 \%$ of the Terai forests were affected due to fire (Sharma, 1996). Moreover, the government- managed forests of Dang, Banke, Kailali and Kapilbastu districts were found to be severely affected by fire (UNECE, 2008).

However, some studies have showed that the disturbance maintains the species diversity (Loucks, 1970; Huston, 1979; Petraitis et al., 1989). Connell (1978) and Grime (1979) had hypothesized that diversity, richness of communities is found highest at intermediate levels of disturbances because species that thrive at both early and late successional stages can coexist. Connell (1978) proposed that relatively low disturbance leads to decreased diversity and high disturbance causes an increase in species movement. Similarly, another study had showed that the anthropogenic and natural disturbances interacted to affect upon the pattern of plant species diversity and composition. The species diversity was sustained by the dynamic attributes of the patches which were generated and modified by disturbances originating from human activities and natural processes (Bhuju and Ohsawa, 2000). According to Levenson (1981), the richness of woody species in isolated woodlots is largely a function of disturbance, whether natural or human induced. He found that the heavy human usage of the urban islands maintains a continual state of disturbance resulting in an increased edge effect (Levenson, 1981).

Prior to the establishment of the Banke National Park (BNK), the area was under the jurisdiction of the Banke District Forest Office, and it went through a series of disturbances such as illegal logging, cattle grazing, cutting and lopping of fodder species which otherwise could have reached the succession stage as in many other protected areas (PAs) of Nepal. Thus, the present study was conducted to: i) assess the regeneration pattern of the BNP, and ii) inspect the impact of human disturbances on natural regeneration of the forests in the BNP, and suggest for the implication of conservation.

\section{Materials and methods}

\section{Study area}

The study was carried out in the BNK of
Western Nepal which was established on 12th July, 2010 as the tenth Park of the nation. It is located between $81^{\circ} 39^{\prime} 29^{\prime \prime}$ to $82^{\circ} 12^{\prime} 19^{\prime \prime}$ East longitudes and $27^{\circ} 58^{\prime} 13^{\prime \prime}$ to $28^{\circ} 21^{\prime} 26^{\prime \prime}$ North latitudes (Figure 1). The total area of the BNK is $550 \mathrm{sq} \mathrm{km}$ with the buffer zone of $343 \mathrm{sq} \mathrm{km}$, and with its Headquarters at Obary (Mahadevpuri VDC) and sector offices at Kusum VDC of Banke district and Chepang VDC of Dang district. The park is linked with trans-boundary landscape that joins Suhelwa Wildlife Sanctuary of India through national and community forests towards south. It is connected with Bardia National Park of Nepal towards west which further links with Katerniaghat Wildlife Sanctuary of India via. Khata Corridor. Most of the park area (77\%) lies in Banke district and some part (23\%) lies in Bardia, Dang, and Salyan districts of the nation.

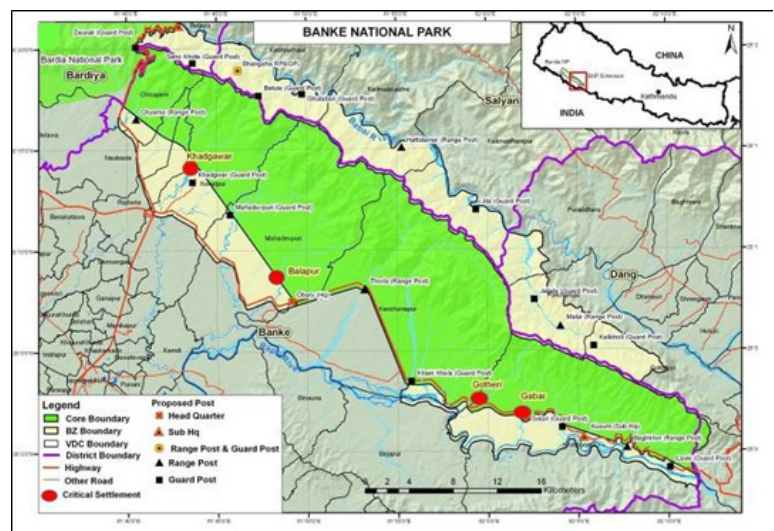

Fig. 1: Location of Banke National Park in the map of Nepal

The topography of the BNK is very diverse- with flood plains, river valleys, gorges and the Churia hills in between Rapti river in the south and Babai river in the north. Its highest elevation is $1,247 \mathrm{~m}$ at Kuine ridge/Phurksalli and the lowest elevation is $153 \mathrm{~m}$ near Dhakeri. This Park has a sub-tropical monsoonal climate with summer monsoon from mid-June to early October followed by a relatively long, cold and dry winter. The temperature variation is high ranging from $10^{\circ} \mathrm{C}$ to $45^{\circ} \mathrm{C}$ in May/June with an average temperature of $23^{\circ} \mathrm{C}$. The hot humid days gives way to monsoon rains that lasts until September.

This park has two bioclimatic zones- tropical and sub-tropical with an array of eight ecosystem types (Sal forest, deciduous Riverine forest, mixed hardwood forest, flood-plains of Terai, Bhabar, foot-hills of Churia range, Savannahs and grasslands. The park encompasses $90 \%$ natural 
forest coverage composed of mainly Sal, Karma, Khair and Sissoo (MFSC, DNPWC and WWF, 1998). Altogether, 124 species of plants (88 trees and climbers and 36 shrub species), 34 mammals, more than 300 birds, 24 reptiles, 7 amphibians and 58 fish species are found in the park. The core area of the park is enclosed all around by buffer zone lying in the 14 VDCs of Banke, Dang, Salyan and Surkhet districts. There are about 4,861 households with 35,712 populations residing in the buffer zone. About $90 \%$ of the economy of the people depends on agriculture while the rest $10 \%$ on trade and labor. The major issues found in this area are deforestation, encroachment, remoteness and poverty.

\section{Sampling design}

The park area was divided into 17 grids $(8 \mathrm{~km} \times 8$ $\mathrm{km}$ ) (Figure 2), and each grid was further divided into 16 sub-grids $(2 \mathrm{~km} \times 2 \mathrm{~km})$ (Figure 3$)$; each grid having 8 sub-grids. In each alternate subgrid at equal spacing of $200 \mathrm{~m}$ (Figure 4), three concentric circular plots with $10 \mathrm{~m}, 5 \mathrm{~m}$, and $1 \mathrm{~m}$ radii were laid out (Figure 5). Altogether, 1,067 sample plots were laid out in the 107 sub-grids excluding the settlement areas. The locations of the sample plots were detected with the help of GPS. All the trees falling within the 10 m-radius plots were recorded. Similarly, all the saplings and seedlings in the plots with $5 \mathrm{~m}$-radius and $1 \mathrm{~m}$-radius respectively were recorded. A set of disturbance variables (Table 3), were recorded in every $10 \mathrm{~m}$-radius circular plots. These variables encompass all the visible signs of disturbance seen around the study site.

Data regarding topography, terrain type, vegetation quantitative data and disturbances

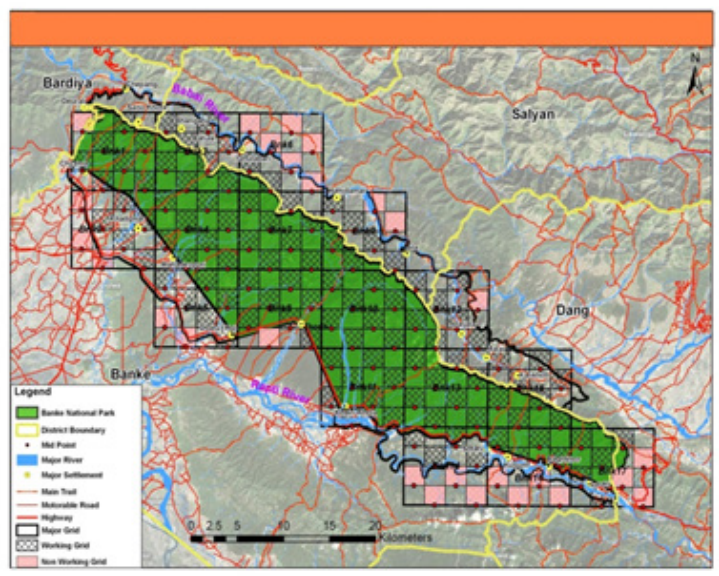

Fig. 2: Division of the entire park into 17 grids and 16 sub-grids were recorded. Regeneration of tree species was calculated by counting the seedlings (height $<20$ $\mathrm{cm}$ ) and saplings (height $<20 \mathrm{~cm}$ but $\mathrm{dbh}<10$ $\mathrm{cm}$ ) as adopted by Sundriyal and Sharma (1996).

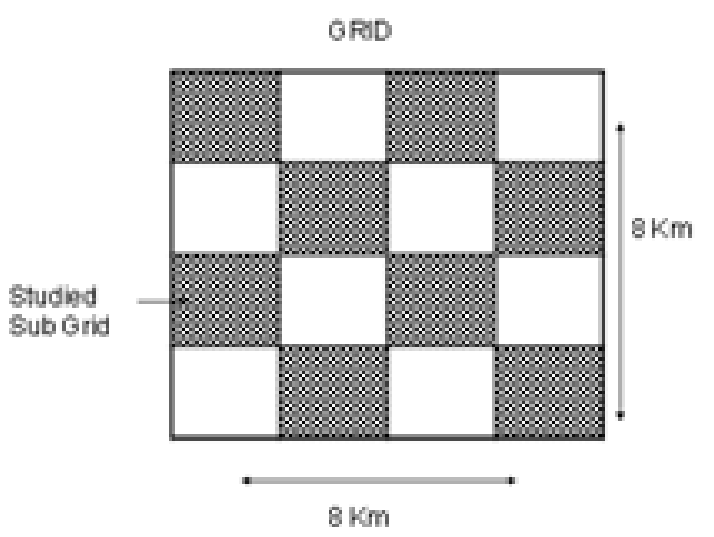

Fig. 3: Grid design for vegetation sampling

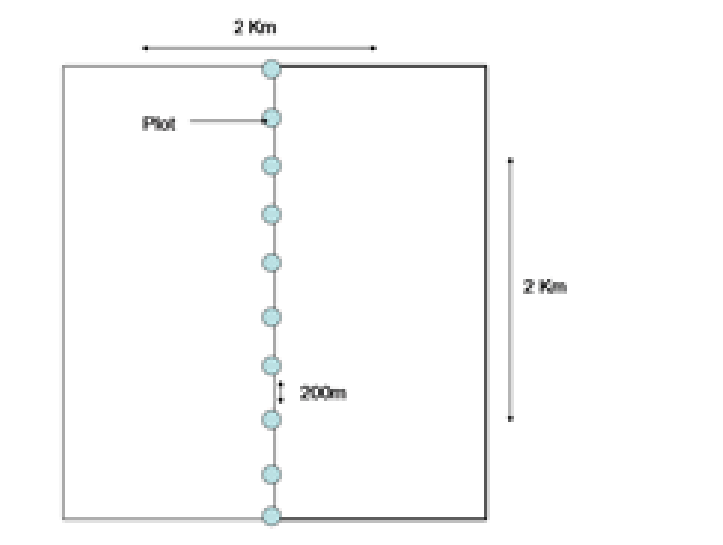

Fig. 4: Plot location in a sub-grid

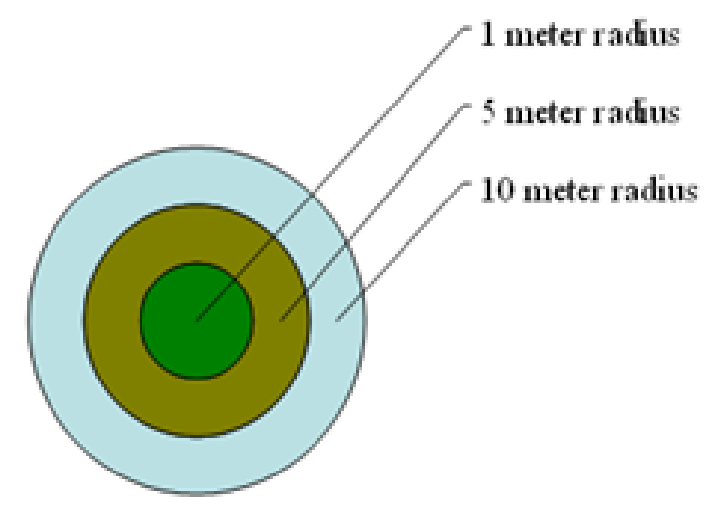

Fig. 5: Layout of the sample plots

\section{Analysis of regeneration status of the forest}

First of all, the densities (number of individuals per hectare) of all the individual trees, saplings and seedlings of tree species were determined. Then, the diameters (dbh) of all the tree species 
were categorized into diameter classes of 10 $\mathrm{cm}$ interval, and then these dbh classes and their densities were used to develop size-class distribution diagram. On the other hand, the relative densities of each tree, sapling and seedling of each tree species were also determined to estimate the population structure of ten dominant tree species of the park.

\section{Analysis of human disturbance and its impact on forest regeneration}

Data on human disturbance were collected from each of the 107 sub-grids. The correlations among 18 disturbance variables were tested using the Kendall Test. Bonferroni Correction was used to maintain the family-wise error rate. It allows to correct significance level of correlation by testing each individual at a significance level of $\alpha / \mathrm{n}, \alpha$ being significance level and n number of sample plots (Dunnett, 1955). As none of the disturbance variables was highly correlated $(r<0.7)$, all the variables were retained in Principal Component Analysis (PCA) to derive a habitat disturbance index (Table 2). The Eigen Value Analysis suggested that a single principle component be retained as a measure of disturbance. To examine relationships between the disturbance variables and natural forest regeneration, a multiple linear regression with forward selection procedure of disturbance variable in the model was used to see the most important variables for seedling and sampling densities. As the objective of this study was to find out whether there is a curvilinear relationship between disturbance index and regeneration status (i.e. seedling and sampling density), a nonlinear regression with a second order polynomial of the form $\left(\mathrm{Y}=\mathrm{pr}_{1}+\mathrm{pr}_{2} * \mathrm{X}_{1}+\mathrm{pr}_{3} * \mathrm{X}_{1}^{\wedge} 2\right)$ was used. For it, observations either with zero disturbance (no disturbance) index or zero regeneration status (no seedling and sampling density) were removed.

\section{Results and discussion}

\section{Forest regeneration status}

The size-class distribution of the stems of the park showed a right skewed and reverse J-shaped distribution with continuous declining frequency in succeeding higher size-class except for size class 20-30 cm (Figure 6).

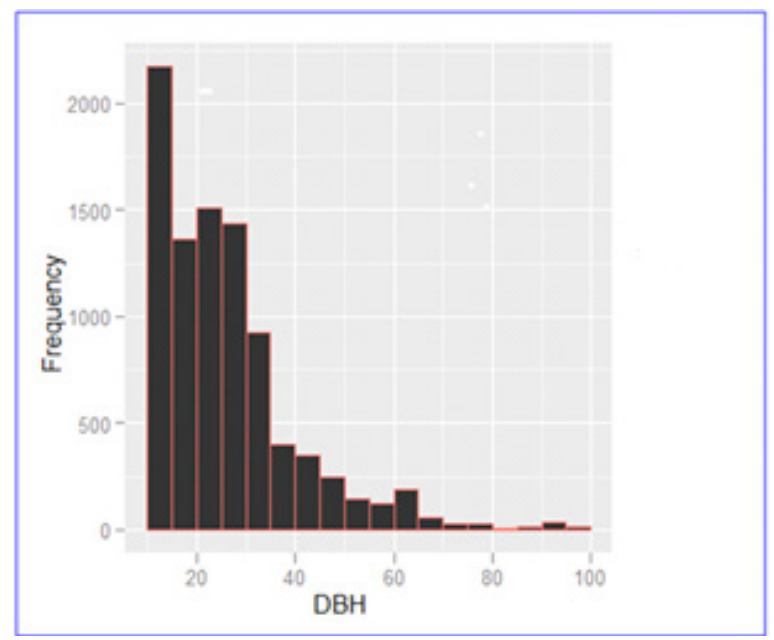

Fig. 6: Tree diameter distribution

\section{Sapling/seedling density}

Altogether, 58 species of sapling and 40 species of seedling of tree species were recorded in the study area. All the sapling density (SD), the seedling density $(\mathrm{SeD})$ and the relative density (RD) were found to be highest for Shorea robusta (SD 200.49 /ha, SeD 27,153.4/ha and RD 58.5) (see Annex 1 attached at the back). In terms of the sapling densities and their relative densities, S. robusta was followed by Murraya koenigii (SD 125.36/ha and RD 16.88) and Terminalia alata (SD 92.62/ha and RD 12.47), while in terms of the seedling and the relative densities, S. robusta was followed by $T$. alata ( $\mathrm{SeD} 5,375.32 /$ ha and $\mathrm{RD} 11.58)$ and by Mallotus philippinensis (SeD 4,652.06/ha and RD 10.02).

Figure 7 (i-x) depicts the population structure of ten dominant tree species on the basis of their relative densities. The dominant tree species, $S$. robusta exhibited higher proportion of seedling and comparatively low density of sapling and tree population. Same was the case for M. philippinensis while Anogeissus latifolius, Acacia catechu, Buchanania latifolia, Ouigenia dalbergoides, Lagerstroemia parviflora and Garuga pinnata were found to have more proportions of trees than seedlings and saplings. On the other hand, T. alata and Diospyrus malabarica had equal proportion of seedlings, saplings and trees. The findings of this study indicated that the regeneration status of $S$. robusta was better than that of all the other species in the BNP. Thus, the ten dominant tree species differed greatly in terms of the densities of seedlings, saplings and trees. 


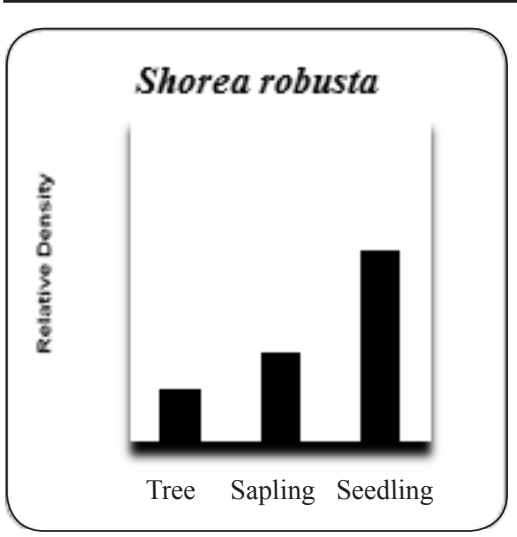

Fig. 7 (i)

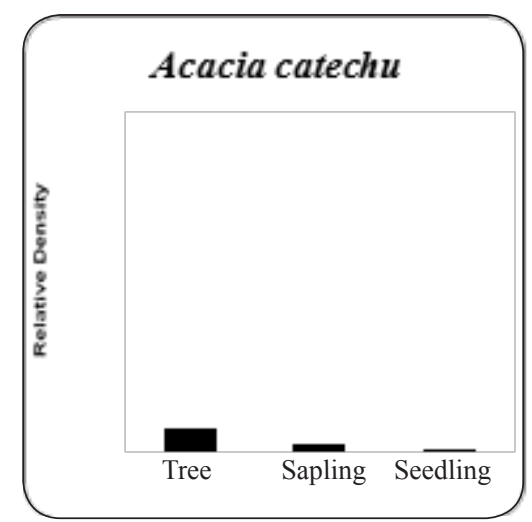

Fig. 7 (iv)

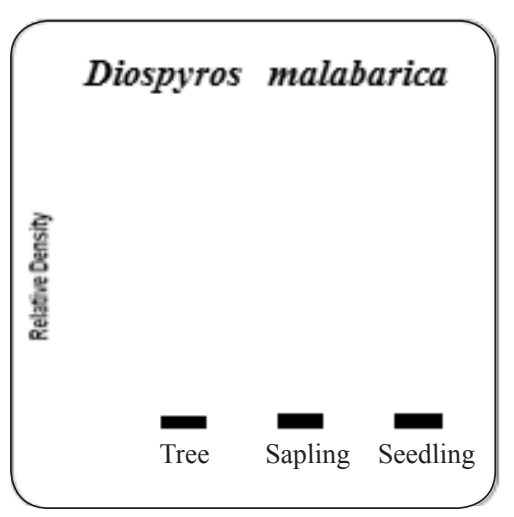

Fig. 7 (vii)

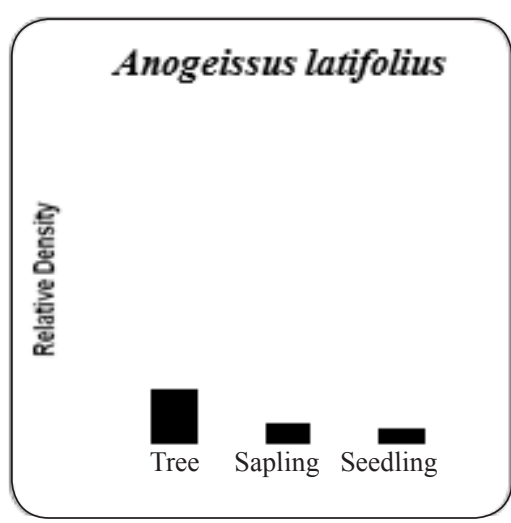

Fig. 7 (ii)

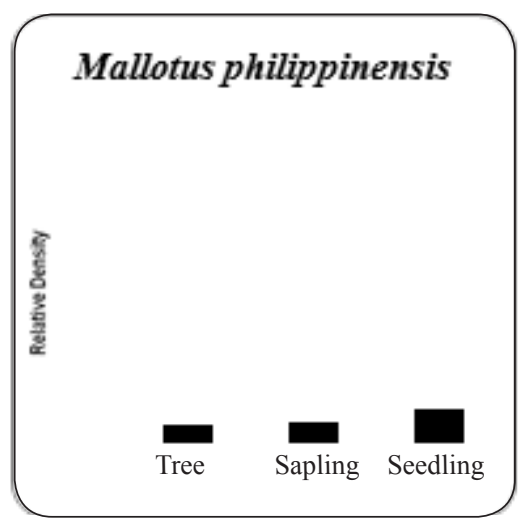

Fig. 7 (v)

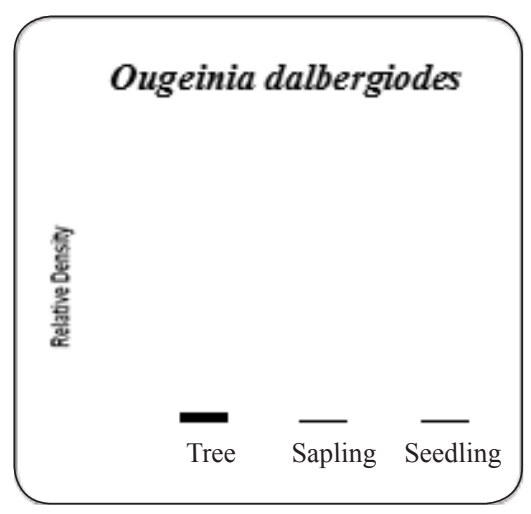

Fig. 7 (viii)

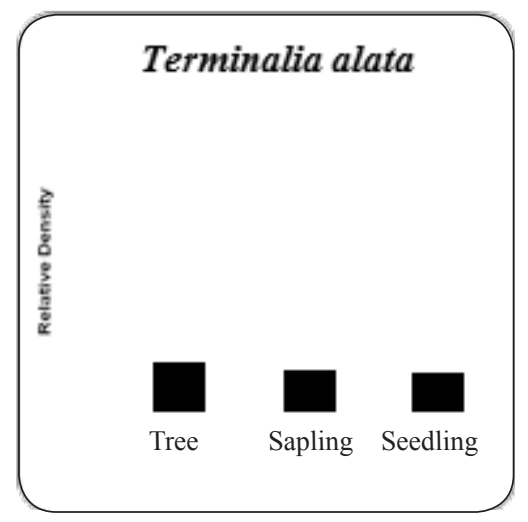

Fig. 7 (iii)

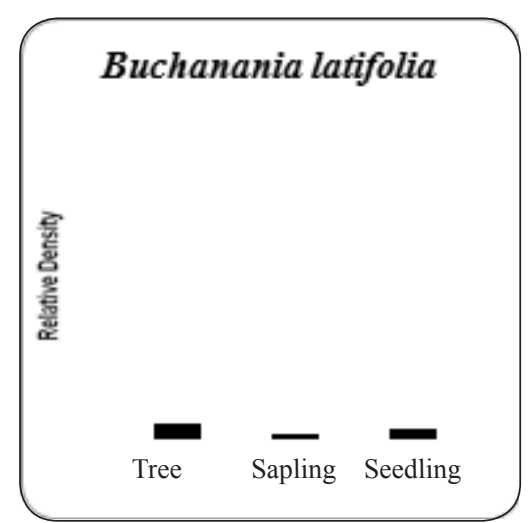

Fig. 7 (vi)

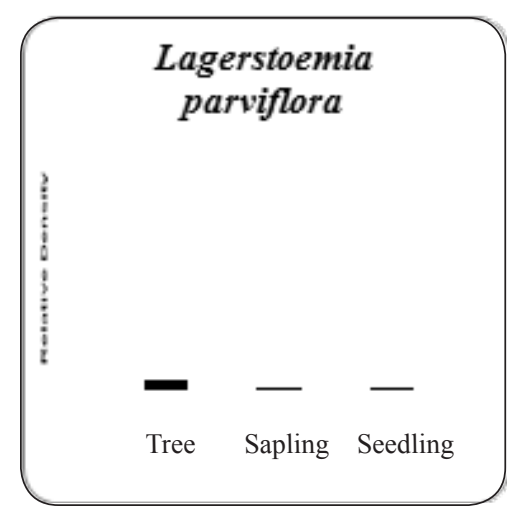

Fig. 7 (ix)

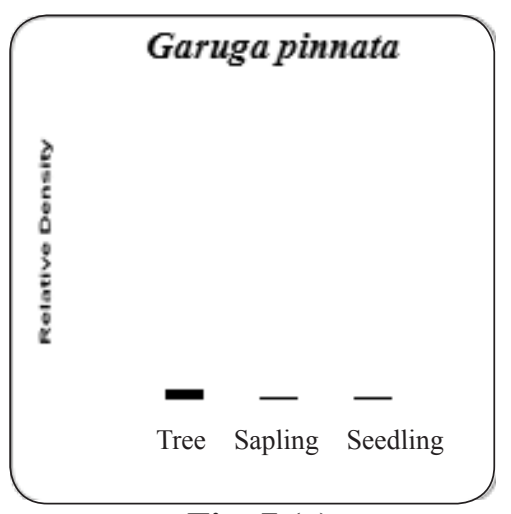

Fig. 7 (x)

Fig. 7 (i-x) : Population structure of ten dominnant tree species of Banke National Park 


\section{Human disturbance analysis}

During the study period, the frequencies of different 18 evidences such as no. of stumps, no. of lopped trees, no. of cultivated patches, no. of fires occurred, no. of cattle grazing and no. of fodder collection noticed during the fieldwork were chosen as disturbance variables for the analysis of human disturbance in the park (Table $1)$.

The Correlation matrix for 18 disturbance variables measured during sampling period in the BNK is presented in Table 2. The matrix reveals that the trails noticed inside the park have positive relationship with the cut-wood found in the forested areas of the park. Similarly, the matrix indicates that the people (carrying weapons) noticed inside the park area, livestock noticed in the park area and the permanent constructions, e.g. huts, sheds etc. made by the people inside the park area have also positive relationship with the cut-wood noticed in the park. Likewise, there is some relationship between the lopped trees and the stumps seen inside the park area. Similarly, the disturbances like fire has positive relationship with lopped tree and stumps found there but negative relationship with wood cutting, temporary and permanent constructions, trails found, livestock and cultivation. Disturbance factors like human settlement has positive relationship with cutting of wood, cultivation, livestock, temporary and permanent constructions, trails found while has negative relationship with lopped tree found, stumps found and fire. Likewise grazing has positive relationship with livestock, trails found, people seen, lopped tree and temporary construction. It has negative relationship with cutting wood, human settlement, stumps found, cultivation and fire. Similarly, a disturbance factor like wood pilling has positive relationship with cutting of wood, stumps and trails. It has negative relationship with lopped tree, cultivation, temporary and permanent construction, lopped tree, fire, and human settlement. While stone mining has positive relationship with cutting wood, stumps and trail found in the area. It has negative relationship with the disturbance factors like lopped tree, stumps, temporary and

Table 1: Disturbance variables used in the analysis

\begin{tabular}{|c|c|c|c|}
\hline Sn & Variables & Symbol & Description \\
\hline 1. & Cut-wood & $\mathrm{CW}$ & Pieces of cut-wood found in each sample plot \\
\hline 2. & Lopped-tree & LT & No. of lopped-tree found in each sample plot \\
\hline 3. & Stump & ST & No. of stump found in each sample plot \\
\hline 4. & Temporary construction & $\mathrm{TC}$ & $\begin{array}{l}\text { No. of temporary constructions made by people, e.g. huts, } \\
\text { sheds etc. }\end{array}$ \\
\hline 5. & Trails & $\mathrm{TR}$ & $\begin{array}{l}\text { No. of distinguishable path (trail) through vegetation due } \\
\text { to frequent human and livestock movement }\end{array}$ \\
\hline 6. & People seen & PS & No. of people observed in each sampling period \\
\hline 7. & Livestock & LS & No. of livestock i.e. cattle seen during the sampling period \\
\hline 8. & Permanent construction & $\mathrm{PC}$ & $\begin{array}{l}\text { No. of permanent constructions made by people in the } \\
\text { sampling site }\end{array}$ \\
\hline 9. & Cultivation & $\mathrm{CU}$ & No. of cultivation sites in each sample plot \\
\hline 10. & Fire & FI & No. of fire signs in each sample plot \\
\hline 11. & People with weapons & PW & $\begin{array}{l}\text { No. of people seen with chopping weapons during the } \\
\text { sampling period }\end{array}$ \\
\hline 12. & Human settlement & HS & No. of human settlement found in the sampling site \\
\hline 13. & Fodder collection & $\mathrm{FC}$ & No. of fodder collection seen during the sampling period \\
\hline 14. & Cut-tree (live) & $\mathrm{CT}$ & $\begin{array}{l}\text { No. of people seen, cutting tree/s, during the sampling } \\
\text { period }\end{array}$ \\
\hline 15. & Grazing & GR & No. of grazing seen during the sampling period \\
\hline 16. & Hunters & HU & $\begin{array}{l}\text { No. of people seen, with hunting weapons, during the } \\
\text { sampling period }\end{array}$ \\
\hline 17. & Stone mining & SM & No. of stone loading seen during the sampling period \\
\hline 18. & Piled-wood & PW & No. of wood piled up in each sample plot \\
\hline
\end{tabular}




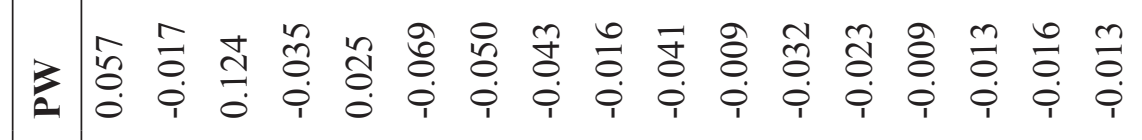

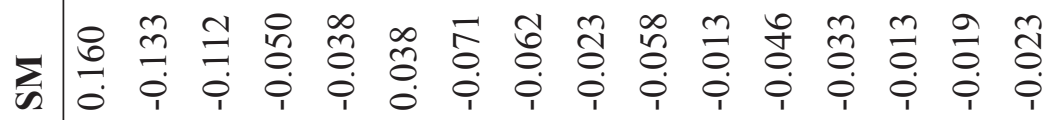

$$
\begin{aligned}
& \text { 引 }
\end{aligned}
$$

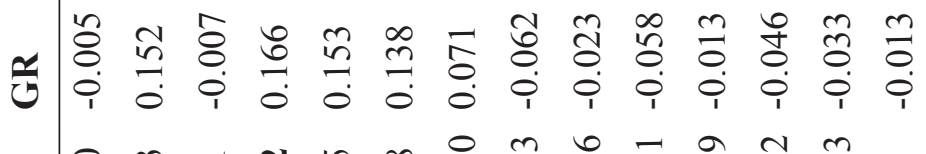

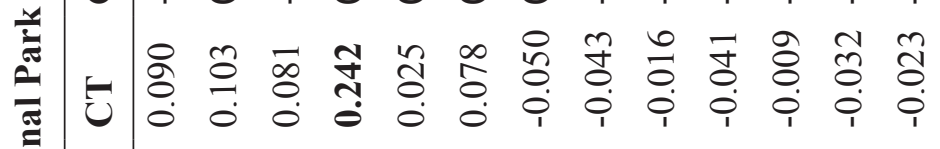

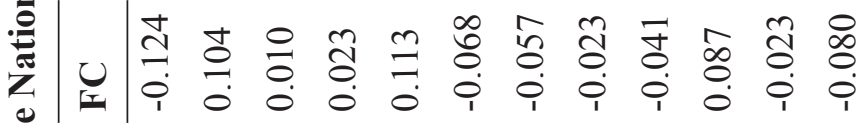

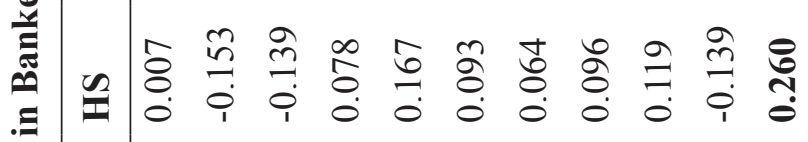

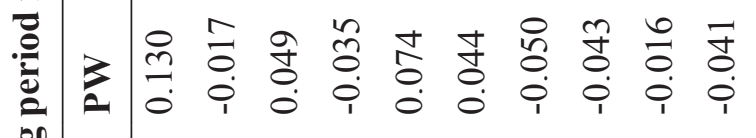

$$
\begin{aligned}
& \text { 量 } \\
& \text { 管 }
\end{aligned}
$$

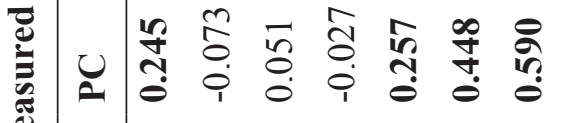

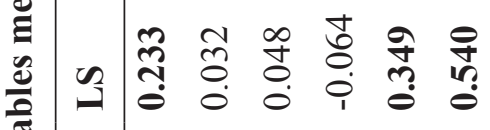

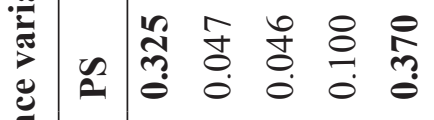

$$
\begin{aligned}
& \text { 总 }
\end{aligned}
$$

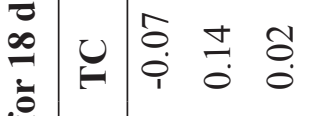

$$
\begin{aligned}
& \text { 战 } \\
& \text { E } \\
& \frac{\pi}{0} \\
& \text { ن } \\
& \text { ن் }
\end{aligned}
$$

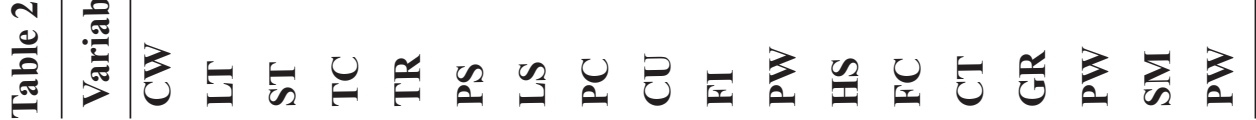


permanent construction, trails, fire, livestock and cultivation.

The analysis of the forward selection multiple linear regression of the sapling density with human disturbance variables showed significant positive association between the sapling density and the human disturbance variables $\left(\mathrm{F}=10.981, \mathrm{R}^{2}=19.3\right.$, $\mathrm{p}<0.0001)$ and the similar association between the seedling density and the human disturbance variables $\left(\mathrm{F}=8.223, \mathrm{R}^{2}=24.2, \mathrm{P}<0.0001\right)$ (Table 3 and 4). The significant disturbance variables selected by a forward selection procedure in multiple linear regressions were cut-wood, livestock, trails and people in the case of sapling density while cut-wood, livestock, trails and stone loading in the case of seedling density. A non-linear regression model of disturbance index against sapling density showed a humpshaped relation with a peak in sapling density in the intermediate disturbance index (Figure 7). It shows that the sapling density of the trees increases with the increase in human-induced disturbances up to a certain limit, and then decreases with further increase in human-induced disturbances. So, the expected curvilinear effect was obtained for the relationship of sapling density and the disturbance index (Figure 8). However, there was no non-linear relationship between disturbance index and seedling density (Figure 9). The expected curvilinear effect was not obtained as it showed only the increase in seedling density with the increase in human disturbance variables.

Table 3: Analysis of multiple linear regression of sampling density with human disturbance variables

\begin{tabular}{cccccc}
\hline Source & DF & $\begin{array}{c}\text { Sum of } \\
\text { squares }\end{array}$ & $\begin{array}{c}\text { Mean } \\
\text { squares }\end{array}$ & F & Pr $>$ F \\
\hline Model & 3 & 0.036 & 0.012 & 10.981 & $<0.0001$ \\
$\begin{array}{c}\text { Error } \\
\text { Total }\end{array}$ & 103 & 0.112 & 0.001 & - & - \\
(corrected) & 106 & 0.148 & - & - & - \\
\hline
\end{tabular}

Table 4: Analysis of multiple linear regression of seedling density with human disturbance variables

\begin{tabular}{cccccc}
\hline Source & DF & $\begin{array}{c}\text { Sum of } \\
\text { squares }\end{array}$ & $\begin{array}{c}\text { Mean } \\
\text { squares }\end{array}$ & F & Pr $>$ F \\
\hline Model & 3 & 0.794 & 0.265 & 8.223 & $<0.0001$ \\
Error & 103 & 3.316 & 0.032 & - & - \\
$\begin{array}{c}\text { Total } \\
\text { (corrected) }\end{array}$ & 106 & 4.110 & - & - & - \\
\hline
\end{tabular}

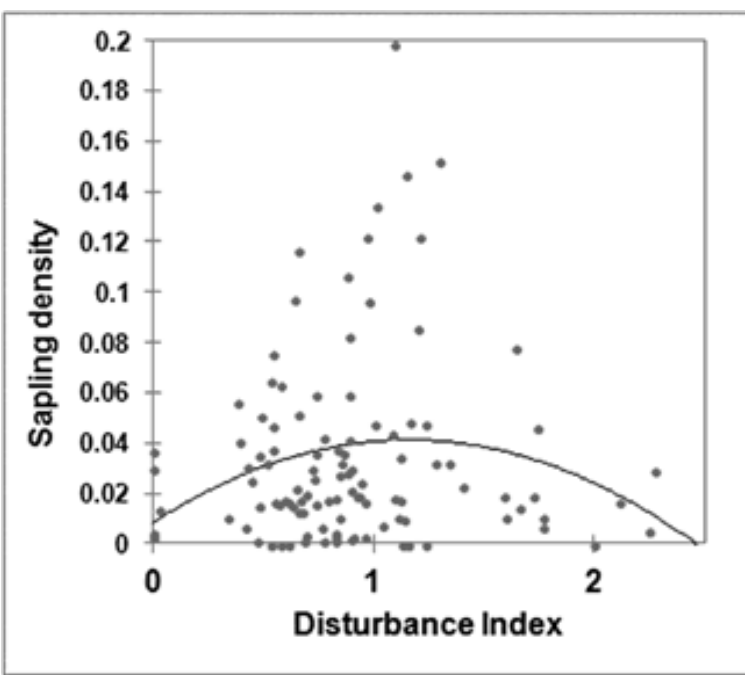

Fig. 8: A nonlinear regression of disturbance index with sapling density

$\left(R^{2}=\mathbf{0 . 1 2 5}\right)$

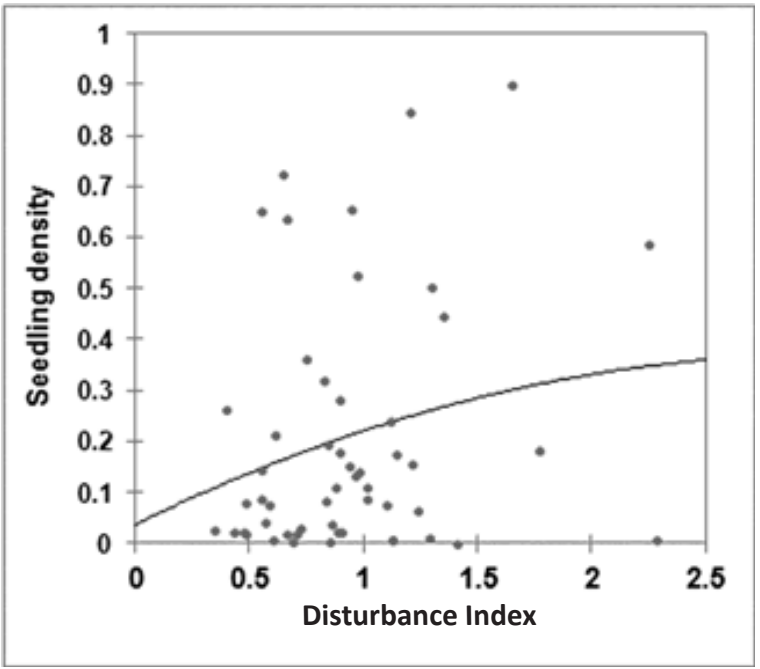

Fig. 9 : A nonlinear regression of disturbance index with seedling density $\left(R^{2}=0.052\right)$

\section{Forest regeneration}

An inverse J-shaped form of size-class distribution of stem indicates a good regenerating capability of the forest. Studies on the size-class structure of forest stands required the full tally method over substantial areas to receive representative results (Schmelz and Lindsey, 1965). Koop (1989) and Piovesan et al. (2005) suggested that 25-40 ha area was required to represent the shifting pattern of the forests. Therefore, small areas might not truly reflect the proportions of the successional stages and over-represent certain structural features.

Besides grazing, canopy cover of dominant trees is also important factor for the establishment of seedling. In high-canopy cover, seedlings cannot 
survive because of the lack of sufficient light while in low-canopy cover, they cannot survive due to high solar radiation. On the other hand, open canopy promotes sapling recruitment and tree growth at early stage. In our study sites, more light was available for the seedlings of S. robusta because of lower density as well as lower canopy cover of trees. Hence, S. robusta had abundant regeneration under the partially open canopy. The regeneration status of tree species like Madhuca butyraceae, Psidium guajava, Dalbergia latifolia, Terminalia bellirica, Bauhinia variegeta was found to be very poor. This indicates that these species could be replaced in near future with other associated species.

Although the forests in the park area had high regeneration potential, all the established seedlings did not get chance to develop into sapling stage due to high human interference like grazing, trampling, forest fire, lopping and unsustainable harvesting of the forest resources. However, all the seedlings cannot survive due to harsh environmental condition and cannot compete with grasses for limited resources.

\section{Human disturbance and its impact on the regeneration of the park}

The influence of seedling and sapling densities on the development and maintenance of any forest is well known. In our study sites, only two of the most dominant tree species, viz. S. robusta and had high seedling and sapling density. This could have a serious conservation implication for forest structure. The findings of our study showed that the intermediate disturbance favored high sapling density; however, the level of disturbance had a positive effect on the seedling density. Increased sapling density in disturbed forests compared to undisturbed forests is in accordance with the intermediate disturbance hypothesis (Connell 1978; Hobbs and Huenneke 1992). Intermediate disturbance hypothesis suggests that disturbances can promote the coexistence of species (Grime 1973; Connell 1978; Huston 1979) and promote high diversity. This does not hold true for seedling density as seedlings occur widespread in every season and they are produced in mass, and are yet to be subjected to disturbance. Thus, sapling density is a good measure to notice influence of human disturbance on forest regeneration status. We found out that the cut-wood, lopped-tree, human/livstock trails and people noticed in a forest area were the most significant variables affecting upon the sapling and seedling densities of the forests in the BNP. These factors create spatial heterogeneity leading to gaps in the forest allowing space for light penetration which favors regeneration to come up. However, the less number of saplings or seedlings even in the relatively undisturbed forests in the park area could be either due to the competition among the intra-species to grow or due to the dense canopy cover causing lack of light for regeneration.

\section{Conclusion}

Despite the forest was open for grazing as well as other human disturbances, the regeneration potential of the park was found to be high. The obtained result from the size class distribution of the trees resembling inverse ' $\mathrm{J}$ ' shape indicates the good regenerating capability of the forest in the park. The findings of 58 species of saplings and 40 species of seedlings of trees in the park also resemble the fairer status of the natural regeneration in the park. Further, the domination of the shrub stratum by some tree saplings indicated good regeneration and self-maintenance ability of the forest.

The findings of our study showed that human disturbance were found to have helped in regeneration of the forests in the BNP only upto certain limit as the sapling densities were found to be low in the forest areas with both low as well as high human disturbances So, this study supports the general hypothesis that intermediate human disturbance, upto certain limit, in a forest affects upon its regeneration status.

\section{Acknowledgments}

We are grateful to WWF Nepal for providing techniques, tools and volunteers for conducting this study. We express our sincere thanks to Dr. Prakash Kumar Paudel for his precious advice and technical support to complete this study. We are thankful to Mr. Sanuraja Maharjan and Ms. Sabita Malla for their valuable suggestions. We appreciate the support of all those who helped us in the fieldwork.

\section{References}

Bhuju, D .R. and Ohsawa, M. 2000. Patch implications in the maintenance of species richness in an isolated forest site. Biological 
Conservation 98: 117-125.

Connell, J. H., 1978. Diversity in tropical rain forests and coral reefs. Science 199: 13021310.

Dunnett, C. W. 1955. A multiple comparison procedure for comparing several treatments with a control. Journal of the American Statistical Association 50: 1096-1121.

Grime, J. P. 1973. Competitive exclusion in herbaceous vegetation. Nature 242: 344-347.

Grime, J. P. 1979. Plant Strategies and Vegetation Processes. Wiley, Chichester.

Hobbs, R. J. and Huenneke L. F. 1992. Disturbance, diversity, and invasions: implications for conservation. Conservation Biology 6: 324-337.

Huston, M. A. 1979. A general hypothesis of species diversity. Journal of The American Naturalist 113: 81-101.

Joshi, A. L., Shrestha, K. and Sigdel, H. 2000. Deforestation and Participatory Forest Management Policy in Nepal.

Koop, H., 1989. Forest Dynamics-SILVI-STAR: A Comprehensive Monitoring System. Springer-Verlag, Berlin, Germany.

Kunwar, R. M. 2004. Forest fire and livelihood linkage in Terai Arc Landscape, Nepal. Report WWF Nepal Program, Kathmandu, Nepal.

Levenson, J. B. 1981. Woodlots as biogeographic island in Southern Wisconsin. In: $R$. L. Burgess and D. M. Sharpe (Editors), Forest Island Dynamic in Man-Dominated Landscape. Springer-Verlag, New York, USA. pp.13-40.

Loucks, O. L. 1970. Evolution of diversity, efficiency, and community stability. American Society of Zoologists 10: 17-25.

MFoSC. 1998. Royal Bardia National Park Extension Area Five Year Operational Plan, 1998-2003. Ministry of Forests and Soil Conservation, Department of National Parks and Wildlife Conservation and World Wildlife Fund Kathmandu Nepal, 2-12.
Panta, M. 2009. Socioeconomic Perspective of Deforestation and Forest Degradation in Nepal. A PHD Thesis, Department of Geoinformatic Engineering, INHA University, Korea.

Petraitis, P. S., Latham, R. E. and Niesenbaum, R. A. 1989. The maintenance of species diversity by disturbance. Quarterly Review of Biology 64: 393-418.

Piovesan, G., D' Filippo, A., Alessandrini, A., Biondi, F. and Schirone, B. 2005. Structure, dynamics and dendroecology of an oldgrowth Fagus forest in the Apennines. Journal of Vegetation Science 16 : 13-28.

Sagar, R. and J. Singh. 2005. Structure, diversity and regeneration of tropical dry deciduous forest of northern India. Biodiversity and Conservation 14 (4): 935-959.

Sapkota I. P., Mulualem, T. and Christer, P. 2009. Species diversity and regeneration of oldgrowth seasonally dry Shorea robusta forests following gap formation. Journal of Forestry Research 20 (1): 7-14.

Sharma, S. P. 1996. Forest fire in Nepal. International Forest Fire News 15: 36-39.

Schmelz, D. V. and Lindsey, A. A. 1965. Sizeclass structure of old-growth forests in Indiana. Forest Science 11: 258-264.

Sundriyal, R. C. and Sharma, E. 1996. Anthropogenic pressure on tree structure and biomass in the temperate forest of Mamlay watershed in Sikkim. Forest Ecology and Management 81: 113-134.

UNECE. 2008. International Forest Fire News. United Nations Economic Commission for Europe. Food and Agriculture Organization of the United Nations. 34: 54-52.

Vetaas, O. R. 2000. The Effect of Environmental Factors on the Regeneration of Quercus semicarpifolia Sm. in Central Himalaya, Nepal. Plant Ecology 146: 137-144. 
Annex1

Per hectare sapling and seedling densities vs. relative densities of the tree species in Banke National Park

\begin{tabular}{|c|c|c|c|c|c|}
\hline \multicolumn{3}{|c|}{ Sapling } & \multicolumn{3}{|c|}{ Seedling } \\
\hline Species & $\begin{array}{c}\text { Density } \\
\text { (trees/ha) }\end{array}$ & $\begin{array}{c}\text { Relative } \\
\text { density }\end{array}$ & Species & $\begin{array}{c}\text { Density } \\
\text { (trees/ha) }\end{array}$ & $\begin{array}{c}\text { Relative } \\
\text { density }\end{array}$ \\
\hline Acacia catechu & 13.33 & 1.8 & Acacia catechu & 375.02 & 0.81 \\
\hline Acer oblongum & 1.31 & 0.18 & Aeglem armelos & 282.75 & 0.61 \\
\hline Adina cordifolia & 0.48 & 0.06 & Annona reticulata & 35.72 & 0.08 \\
\hline Aegle marmelos & 2.86 & 0.38 & Anogeissus latifolius & 1872.14 & 4.03 \\
\hline Annona reticulata & 0.71 & 0.1 & Bauhinia variegata & 5.95 & 0.01 \\
\hline Anogeissus latifolius & 39.41 & 5.31 & Buchanania latifolia & 1556.64 & 3.35 \\
\hline Anthocephalus cadamba & 0.24 & 0.03 & Cassia fistula & 29.76 & 0.06 \\
\hline Psidium guajava & 0.83 & 0.11 & Chitana & 89.29 & 0.19 \\
\hline Bauhinia variegata & 0.71 & 0.1 & Dadrung & 44.65 & 0.1 \\
\hline Bire & 0.12 & 0.02 & Dalbergia latifolia & 2.98 & 0.01 \\
\hline Bisaindha & 0.12 & 0.02 & Dillenia pentagyna & 264.9 & 0.57 \\
\hline Bredelia retusa & 1.67 & 0.22 & Diospyro stomentosa & 2095.36 & 4.51 \\
\hline Buchanania latifolia & 14.29 & 1.92 & Feroni alimonia & 193.46 & 0.42 \\
\hline Careya arborea & 0.6 & 0.08 & Ficus hispida & 104.17 & 0.22 \\
\hline Cassia fistula & 2.86 & 0.38 & Ficus nimarolis & 130.96 & 0.28 \\
\hline Chhitaina & 13.57 & 1.83 & Gaipaile & 5.95 & 0.01 \\
\hline Chittabayer & 30.24 & 4.07 & Ganaune & 14.88 & 0.03 \\
\hline Dadrung & 0.95 & 0.13 & Garuga pinnata & 35.72 & 0.08 \\
\hline Dillenia pentagyna & 7.02 & 0.95 & Katkute & 2.98 & 0.01 \\
\hline Diospyro stomentosa & 37.15 & 5 & Kerauta & 5.95 & 0.01 \\
\hline Dudkhirro & 0.95 & 0.13 & Lagerstroemia parviflora & 74.41 & 0.16 \\
\hline Ficus bengalensis & 0.24 & 0.03 & Litsea monopslata & 125.01 & 0.27 \\
\hline Ficus hispida & 3.57 & 0.48 & Luhati & 5.95 & 0.01 \\
\hline Ficus nimarolis & 1.55 & 0.21 & Madhuca butyraceae & 5.95 & 0.01 \\
\hline Ficuss emicordata & 1.43 & 0.19 & Mallotus philippinensis & 4652.06 & 10.02 \\
\hline Garuga pinnata & 0.71 & 0.1 & Murraya koenigii & 580.39 & 1.25 \\
\hline Jangali bayer & 0.36 & 0.05 & Myrsine semiserrata & 193.46 & 0.42 \\
\hline Katkute & 1.07 & 0.14 & Ougeinia dalbergiodes & 172.63 & 0.37 \\
\hline Lagerstroemia parviflora & 2.14 & 0.29 & Parula & 2.98 & 0.01 \\
\hline Litsea monopslata & 2.74 & 0.37 & Phyllanthus emblica & 59.53 & 0.13 \\
\hline Madhuc abutyraceae & 0.12 & 0.02 & Schleichera obleosa & 89.29 & 0.19 \\
\hline Mahuli & 0.12 & 0.02 & Semicarpus anacardium & 172.63 & 0.37 \\
\hline Main kanda & 46.67 & 6.28 & Shorea robusta & 27153.4 & 58.5 \\
\hline Makare & 0.12 & 0.02 & Syzygium cumini & 398.83 & 0.86 \\
\hline Mallotus philippinensis & 44.65 & 6.01 & Anthocephalus chinensis & 5.95 & 0.01 \\
\hline Melia azedarach & 4.41 & 0.59 & Terminalia alata & 5375.32 & 11.58 \\
\hline Morus alba & 0.36 & 0.05 & Terminalia bellirica & 2.98 & 0.01 \\
\hline Murraya koenigii & 125.36 & 16.88 & Terminalia chebula & 29.76 & 0.06 \\
\hline Myrsinese miserrata & 7.38 & 0.99 & Unidentified seedling & 2.98 & 0.01 \\
\hline Ougeinia dalbergiodes & 2.98 & 0.4 & Zizyphus jujuba & 166.68 & 0.36 \\
\hline Phyllanthus emblica & 0.83 & 0.11 & Total & 46419.43 & 100 \\
\hline Pipari & 0.24 & 0.03 & & & \\
\hline Psidium guajava & 0.12 & 0.02 & & & \\
\hline Sano Gayo & 0.24 & 0.03 & & & \\
\hline Schleichera obleosa & 0.6 & 0.08 & & & \\
\hline Semicarpus anacardium & 1.43 & 0.19 & & & \\
\hline Shorea robusta & 200.49 & 26.99 & & & \\
\hline Sidaura & 0.83 & 0.11 & & & \\
\hline Sterculi avillosa & 1.9 & 0.26 & & & \\
\hline Surain & 0.12 & 0.02 & & & \\
\hline Syzygium cumini & 11.79 & 1.59 & & & \\
\hline Anthocephalus chinensis & 0.12 & 0.02 & & & \\
\hline Terminalia alata & 92.62 & 12.47 & & & \\
\hline Terminalia bellerica & 0.48 & 0.06 & & & \\
\hline Terminalia chebula & 1.19 & 0.16 & & & \\
\hline Unidentified & 0.48 & 0.06 & & & \\
\hline Wendlandia exserta & 4.52 & 0.61 & & & \\
\hline Zizyphus jujuba & 9.41 & 1.27 & & & \\
\hline Total & 742.78 & 100.00 & & & \\
\hline
\end{tabular}

